This item was submitted to Loughborough's Research Repository by the author.

Items in Figshare are protected by copyright, with all rights reserved, unless otherwise indicated.

\title{
(Not) learning from the past? The diffusion of the EU's rural development policy in its neighbouring countries
}

PLEASE CITE THE PUBLISHED VERSION

https://doi.org/10.1080/19448953.2017.1367586

\section{PUBLISHER}

(c) Taylor \& Francis

\section{VERSION}

AM (Accepted Manuscript)

\section{PUBLISHER STATEMENT}

This work is made available according to the conditions of the Creative Commons Attribution-NonCommercialNoDerivatives 4.0 International (CC BY-NC-ND 4.0) licence. Full details of this licence are available at: https://creativecommons.org/licenses/by-nc-nd/4.0/

\section{LICENCE}

CC BY-NC-ND 4.0

\section{REPOSITORY RECORD}

Kourtelis, Christos. 2019. "(not) Learning from the Past? the Diffusion of the Eu's Rural Development Policy in Its Neighbouring Countries”. figshare. https://hdl.handle.net/2134/32528. 


\title{
(Not) Learning from the Past? The diffusion of EU's rural development policy in its Neighbouring Countries
}

\begin{abstract}
After the Arab revolts the EU attempted to contribute to the rural development of the Arab Mediterranean states by designing the European Neighbourhood Programme for Agriculture and Rural Development (ENPARD). Through ENPARD the EU tried to diffuse policies that were implemented in the New Member States (NMS) and the candidate countries. Based on the experiences of one NMS (Croatia) and one candidate country (Turkey), the article surveys what is (not) learned from the pre-accession programmes and the limits of policy diffusion in Egypt and Tunisia. The article claims that policy diffusion must be distinguished from policy convergence and that policy success must be contextualised by taking into account the role of domestic actors in each case study.
\end{abstract}

Keywords: ENP, ENPARD, policy diffusion, rural development

\section{Introduction}

The interest of analysts about the transfer of EU norms and rules to the European Neighbourhood Policy (ENP) countries is not new. Under the umbrella of Europeanisation, a vast part of the literature sees the ENP as a platform through which the EU attempts to transfer to the national administrations of the partner countries all the norms and rules that the EU members share. ${ }^{1}$ Yet, despite the increasing body of works about policy diffusion in the ENP countries, there is a gap in the literature about the diffusion of rural development policies in the EU's neighbouring countries. Especially for the Euro-Mediterranean relations, the scholarly focus has been so far on the costs of agricultural trade and not on the transfer of rural development policies to the Arab Mediterranean countryside. ${ }^{2}$

Yet after the Arab revolts the ENP has entered a new phase and regarding the rural development of the ENP countries the EU has decided to draw concrete lessons from the accession programmes in order to improve the life of rural populations of its partners. ${ }^{3}$ The main aim of the EU was to make the new ENP more objective and effective and towards this direction it created ENPARD. ENPARD is based on the older Special Accession Programme for Agriculture and Rural Development (SAPARD) and on the Instrument for Pre-Accession Assistance in Rural Development (IPARD). ${ }^{4}$ IPARD and SAPARD were considered as successful tools for the development of agriculture in Turkey and in the Balkan countries. ${ }^{5}$ Based on this 
success, EU policymakers are optimistic about the effectiveness of ENPARD in the North African partners.

The article questions this mechanistic optimism of the EU's policymakers. It argues that the achievements of these policies must be contextualised and that crucial to their successful diffusion is the role of domestic actors. In order to offer a clearer picture of the role that domestic actors play in each context, the article compares the application of SAPARD and IPARD in Croatia and Turkey with ENPARD in Tunisia and Egypt, which first implemented the programme in the Southern rim of the ENP.

The paper starts by explaining the literature of policy diffusion mechanisms in the ENP countries. What follows is a section with the norms and principles of rural development that the EU wants to diffuse to the Arab Mediterranean partners after 2010. The article proceeds by explaining the rural development policies of Croatia and Turkey; how these were supported by the EU programmes and which factors counted for the success of the EU initiatives. After this part, the study assesses the Tunisian and Egyptian reforms for rural development. Contrary to the Croatian and closer to the Turkish experience, the paper argues that the aim of the North African rural development policy so far supports mainly big farmers. This orientation of the North African governments has contributed to the creation of a dual agricultural market and ENPARD does not mitigate the wealth gap between the richer and poorer producers of the North African agricultural communities.

\section{Mechanisms of policy diffusion in the EU's neighbourhood}

As stated in the introduction studies that have tried to explore the EU's impact on the domestic policies of the ENP partners have grown significantly in the last decade. Mostly students of Europeanisation have analysed the conditions and the causal mechanisms for the diffusion of EU policies in the ENP countries and to what extent the ENP is a new threshold for the relations of the EU with its Mediterranean partners. ${ }^{6}$

Despite the fact that the literature on policy diffusion is heterogeneous and it draws lessons from different schools of thought, it shares the view that policy diffusion refers to the processes that might result in increasing policy similarities across countries. ${ }^{7}$ The literature suggests that the ENP governments do not adopt EU policy practices randomly, but through common affiliations, negotiations and participation in the same institutions. This assessment led many studies to map the various mechanisms of policy diffusion and the reasons for adoption patterns.

The first mechanism that is used for the diffusion of policies is coercion. However, in practice the EU very rarely uses coercion against its neighbours. As Holden has correctly mentioned aid has become more important than hard power in the EU external affairs towards its Mediterranean partners. ${ }^{8}$ This brings to the surface the second mechanism, which is related 
to the use of (positive or negative) incentives for promoting institutional models. Rewards, financial and technical assistance and in the case of the ENP the 'more-for-more' approach of the EU concerns diffusion through manipulating the utility calculations of the partner countries.

The third mechanism that many studies explore is learning. This is the process where policymakers observe policies that have been adopted elsewhere and learn from the experiences of others. In this regard the EU is perceived as teacher of norms and practices. An important element of this mechanism is the process of socialisation through which partners redefine their identities and interests. ${ }^{9}$ In this case the European Commission (EC) and the other EU agencies become socialisation platforms, which communicate rules, norms and practices to the ENP partners.

In reality these mechanisms hardly operate in isolation and as Börzel and Risse mention none of these mechanisms assumes that the EU neighbours should be considered as passive decision takers. ${ }^{10}$ The EU partners have their own systems of beliefs through which they filter the EU policies and rules. Often met with skepticism or resistance the EU practices are incorporated into the existing structures rather they replace them. Radaelli highlights the importance of these particularities arguing that the political context at the receiving end of the EU policies can lead to policy diffusion without convergence. ${ }^{11}$

At this point it is necessary to explain the differences between diffusion and convergence. As stated above policy diffusion is a process which leads to similarities between countries, but these similarities can stay at the level of discourse (such as the adoption of similar principles) and to the adoption of some commitments. This type of diffusion should not be confused with convergence at the level of the use of instruments or convergence of results. ${ }^{12}$ In other words the successful diffusion of norms and principles does not necessarily indicate the successful implementation of commitments (in this paper support to smaller farmers of the ENP countries through the use of ENPARD). The article builds on this distinction between diffusion and convergence. The next section explains what the EU tries to diffuse in the area of rural development to the neighbouring countries after the Arab revolts.

\section{The EU Rural development policy: What does the EU try to diffuse in the ENP countries?}

As the price-distorting mechanisms of the Common Agricultural Policy (CAP) were under attack from groups both within and outside Europe, EU policymakers were forced to reform rural support policies. Deviating from the large-scale state investments in infrastructure, EU rural development reforms attempted to promote the concept of integrated rural development. In practice the launch of the first integrated rural development programme in the EU was implemented in 1982 in ten pilot rural areas of different member states; ${ }^{13}$ but the principles of the EU rural development policy became an integral part of the EU discourse after the first European Conference on Rural Development in Cork in 1996. 
The focus of the new approach was on small and medium scale industries and rural services. The concept advocated the economic diversification of the income base of family farms and the incorporation of the different aspects of rural development (such as the management of natural resources and the enhancement of environmental functions) in one legal and policy framework. In addition, the new concept supported the modernisation of the local and regional administration and the exchange of experiences through networks between regions and rural communities. ${ }^{14}$

Deviating from the top-down experience of the previous policies, the new concept invited local farmers to contribute to the design and the implementation of rural development projects through the creation of Local Action Groups (LAGs). LAGs are local partnerships between farmers, trade unions, local political representatives and other community service providers (such as women and youth organisations), which are responsible for identifying and implementing local development strategies and making decisions about the allocation of financial resources.

The new integrated approach for rural development aimed to bring convergence to the disadvantaged regions of Europe and to the fragile rural economies of the NMS and candidate countries. For EU policymakers this model could be diffused to the countries of North Africa, as the Arab revolts in Egypt and Tunisia have highlighted abject rural poverty, regional disparities and neglect of rural areas. For the former commissioner of Agriculture and Rural Development Dacian Cioloş ENPARD sends a clear signal of the EU's willingness to put agriculture back at the core of its relations with the ENP partners. According to him the EU was ready

to share our experience, our know-how, in the framework of a solid partnership for rural development and for the sustainable valorisation of these regions' agricultural potential. That is the meaning of ENPARD programmes. It is not merely about funding, but also about working methods, which have been shown to be effective, in particular during the accession of the new EU member states. ${ }^{15}$

In the same vein, the former Commissioner of Enlargement and ENP Štefan Füle added that the diffusion of the working methods that have been successful to the NMS will help to achieve the aims of the new ENP, namely to contribute to more employment in rural areas and to support inclusive growth. ${ }^{16}$ However, this mechanistic approach of EU policymakers is not accurate. As the next case studies show the success of integrated rural development depends on the role of domestic actors. The next sections analyse the diffusion of the EU rural development policy in different contexts and to what extent the results in each case converge with each other. 


\section{The implementation of the pre-accession programs in Croatia and Turkey}

During the accession period, the development of agriculture was one of the main priorities for the Croatian government and it still is for the Turkish administration. The share of agriculture in the national GDP of both countries, the size of agricultural land and the people that live in rural areas were (and still are) much higher than the EU average. For example, 48 per cent of the Croatian people live in rural areas and the agricultural sector adds almost 10 per cent to the national GDP. ${ }^{17}$ In Turkey agriculture adds more than 8 per cent to the national GDP and 25 per cent of the total population lives in rural areas. ${ }^{18}$ To support the agricultural sector of the two countries, the EU has created SAPARD and IPARD. SAPARD started in 1999 and it was implemented only in Croatia. ${ }^{19}$ This was replaced by IPARD in 2007 and its funds have been used by both countries. The priorities of the programmes were identified in the Accession Partnerships that the two countries negotiated with the EU. Their objectives were to enhance the competitiveness of the local farmers and to help the two countries implement the EU acquis in order to prepare them for the CAP.

In Croatia SAPARD relied on the Agriculture and Rural Development Plan (ARDP). The programme lasted for two years (2005-06) and was replaced by a second ARDP for the implementation of IPARD in 2007. This programme ended with the accession of the country in the EU in 2013. ${ }^{20}$ Following the aforementioned principles of integrated rural development, the ARDP of 2005-06 was the first comprehensive attempt to support the national agricultural sector. The aim of the previous Croatian plans was only to increase the national production without any specific measures for rural development. Until the end of 1990s most agricultural measures were taken from the previous Yugoslavian legislation and even when some reforms were introduced in 1999, due to demands of the World Trade Organisation, these focused on direct price subsidies and trade policies. ${ }^{21}$ Rural development was linked to market policies and was perceived as an automatic outcome generated by increased productivity. ${ }^{22}$ The failure of these plans to improve the competitiveness of the sector resulted to massive flows of people towards the urban centers and contributed to the depopulation of the rural areas. Furthermore, the underdeveloped infrastructure in rural areas and the problematic access of the rural population to public institutions added more constraints to the development of agriculture.

Domestic pressures for the decentralisation of the decision-making process and the increasing role of the Croatian civil society in rural areas led the Croatian Ministry of Agriculture to adopt a multi-sectoral approach for the development of the sector. Due to the tragedy of the war in the 1990s Tudjman created an even more centralised structure than the communist government. The share of the local authorities from the national budget was much lower than the pre-war years; the funds for the regional authorities were just one third of the pre-war revenues. ${ }^{23}$ After the end of the Tudjmanist era, the successive right-wing government tried to 
increase its legitimacy by reinforcing the existing centralised structures. Funds towards the local governments remained low and in addition the central administration extended its control to services that were provided by local authorities. The situation changed when a center left-wing coalition government took power at the beginning of 2000s. The new administration soon realised that the suffocation of the local authorities and their limited role in public spending and affairs were significant barriers for the implementation of domestic policies. ${ }^{24}$ Trying to support the transition from authoritarian to democratic rule, the new government saw decentralisation reforms and the diffusion of the EU rules as a pillar of a functioning democracy and market economy.

These reforms included a new institutional framework, which gave back to regional authorities the control of social services that were managed by the central government. New laws improved local financing and were followed by civil service reforms that made the local authorities more efficient. Regarding the implementation of the EU initiatives for supporting agriculture, the Croatian authorities followed a similar decentralised approach. ${ }^{25}$ The Paying Agency for IPARD organised five regional offices in Zagreb, Bjelovar, Osijek, Rijeka and Split. In addition, the Croatian government created twenty-one regional offices, which had increased responsibilities. These ranged from assisting farmers for getting funding from the EU programmes to offering help for quality controls and advice for creating integrated agricultural projects.

The role of Civil Society Organisations (CSOs) was also important for the diffusion of the EU rural development programmes. Despite being at an infant stage and with few funds and resources, CSOs have done considerable progress since the end of the civil war and they offered services that the state was unable to provide in rural areas. ${ }^{26}$ The role of CSOs in informal education, such as training and planning, was crucial for raising the awareness of the local farming communities about new producing methods and EU funding channels. Their work in rural areas forced the Croatian administration to involve local businesses and civil society in government plans in order to give a new momentum to the agricultural sector and rural development. ${ }^{27}$ Besides efforts to apply the EU principles in programming, the new plan identified priority areas of rural development and attempted to support bottom-up solutions to local problems. By strengthening regional associations and local organisations, the new plan showed that the participation of local actors was an integral part of the new policy. Local NGOs became more visible partners for the convergence of rural development policies and in the implementation of the related programmes. The Croatian Rural Development Network, which had lobbied the Croatian government for a more inclusive rural development policy since 2004, became the official umbrella of local NGOs (which focused on rural development) in 2006. It got the ability to monitor rural development policies and to propose measures for improving the application of related projects. 
Regarding the political economy of agriculture, the different dimensions of SAPARD and IPARD focused on two priorities. The first one was to assist the consolidation of agricultural holdings and the second was to diversify the income of the rural population. Land fragmentation was considered as one of the main reasons for the low productivity of the Croatian farmers and through various projects the Croatian government tried to reshape agricultural holdings. ${ }^{28}$ With the assistance of the Swedish administration, the Croatian government designed a three-year land consolidation project, which changed the structure of farms in different rural areas, such as the municipalities of Vinodolska and Vidovec. ${ }^{29}$ Consistent with its bottom-up approach, an essential part of the project was to include actors of all levels in the decision-making process.

Even if land consolidation projects were progressing slowly, due to administrative problems (such as land registration and the simultaneous creation of a modern cadastre) the results in the pilot areas were welcomed by the local communities, as they had improved the structure of farms and the efficiency of the agricultural land market. ${ }^{30}$ SAPARD and IPARD complemented these projects by offering financial support to middle sized farms and producers. Due to pressures from small farmers, the Croatian government supported smallscale producers for improving their productive capabilities. ${ }^{31}$ The logic of the programmes was to help small farmers expand their production, through the adoption of new marketing strategies.

Yet, and despite the inclusion of different actors in the new government plans, administrative problems did not allow the Croatian farmers to absorb a large part of the funds allocated by SAPARD. Actually, the programme was mostly used as a mechanism for the modernisation of the Croatian state agencies. The decision of the Croatian government to focus more on the modernisation of the Croatian administration was crucial for the better implementation of IPARD, which replaced SAPARD in 2007. ${ }^{32}$ From 2007-13 the EU funds were significantly increased, as the total investments exceeded $€ 300 \mathrm{~m}$. Being better prepared for the application of IPARD, the Croatian administration allocated these funds to farmers and rural communities.

The popularity of IPARD among the Croatian farmers led the government to organise extensive public discussions about the use of the resources from IPARD and to improve the procedures for funding. Regarding the second aim of the programmes (rural development) more emphasis was given to rural tourism and to the support of Small and Medium Enterprises in rural areas. The creation of LAGs (in areas between 5,000 - 150,000 people) increased further the Croatian absorption of IPARD funds, as almost $€ 3 \mathrm{~m}$ have been channeled to such partnerships, which offer training and support to local businesses. ${ }^{33}$

Yet, the conclusion of EU policymakers that the Croatian IPARD is a complete success story is not accurate. Several obstacles hampered the operation of the programme. Qualitative 
analyses show that the administrative problems are not a subject of the past. The decentralisation initiatives of the Croatian government were controlled from above and undermined the efficiency of the programme. ${ }^{34}$ The poor coordination between the central and local administrative bodies led to delays in the dissemination of the relevant information, meaning that beneficiaries often missed crucial deadlines. Even if the absorbing capacity of the Croatian administration increased, the local authorities managed to absorb 50 per cent of the total commitments between 2007-13. ${ }^{35}$ In addition, IPARD's uniform funding criteria did not take into consideration the different conditions in the Croatian rural areas. Sub-sectors of the Croatian agricultural economy, without strong political influence, such as floristry and honey producers, were not eligible to apply for support. Between the two priorities of the programme (market efficiency and rural development) the latter received less attention. According to the Croatian Rural Development Network, LAGs were the only CSOs that were eligible to get funds from IPARD. Other civil society actors and NGOs that could further increase the visibility of the program and improve the aspects of IPARD related to rural development could not apply for funds from the EU initiatives. ${ }^{36}$

The success of IPARD is even smaller in Turkey. SAPARD, which was used as a vehicle for the modernisation of the Croatian administration, was not implemented in Turkey, as the country was not ready for negotiating the agriculture chapter of its membership. The EU put on hold discussions about the Turkish agricultural reforms in 2006 (due to problems between Turkey and Cyprus) ${ }^{37}$ but besides the Cypriot-Turkish dispute, the absence of a designated body for the management of the EU funds did not allow the implementation of EU tools in the sector. ${ }^{38}$ The creation of the Turkish IPARD Paying Agency early in 2007 allowed the EU to approve the implementation of IPARD in Turkey in December 2007. From 2007-13, the EU decided to allocate through IPARD more than $€ 873 \mathrm{~m}$ to the country.

Contrary to the Croatian case, the Turkish administration saw IPARD, as a tool to support large-scale producers and the rich regions of the country. Since the beginning of 2000s and during the membership negotiations the Adalet ve Kalkınma Partisi (Justice and Development Party; AKP) introduced several agricultural reforms to replace state subsidies with direct income transfer programmes. ${ }^{39}$ The removal of artificial incentives and the restructuring of sales cooperatives reduced the budget expenses to farmers by 30 per cent only in the first years of their implementation. Yet, these changes did not alter the status quo in rural areas and wealthier farmers continued to benefit from the reforms. Market oriented reforms did not change the regional distribution of income either. In fact the new agricultural policies widened the gap between the poorer and wealthier regions of Turkey both in relative and absolute terms. $^{40}$

The insistence of the AKP to benefit disproportionally the wealthiest segments of the Turkish rural communities was obvious during the negotiations with the EU for the regions that 
would be funded by IPARD. This issue created a dispute between Turkey and the EC for the implementation of the programme. The EC insisted to channel funds to the poorer areas of the country and with GDP per capita below the 75 per cent of the Turkish average. On the other hand, the Turkish Ministry of Agriculture claimed that the richer regions should qualify as well, as they had more potential for further growth. ${ }^{41}$ The result was a compromise between the two sides. For the period 2007-13, the qualified 42 provinces were selected for the potential they had, the GDP per capita and net internal migration.

An additional problem for more inclusive strategies that could develop the Turkish agricultural sector was the weak civil society in the rural areas of the country. An equivalent network to the Croatian Rural Development Network does not exist yet in Turkey and LAGs are at an embryonic stage, unable to absorb any funds from IPARD. ${ }^{42}$ Suggestions for setting up young farmers organisations, institutions that could strengthen producers' voice and women's participation in rural development remain policies in paper. ${ }^{43}$ This situation and the inability of small producers to get access to credit make small agro-businesses vulnerable to the volatility of the market. Some credit schemes, which have been supported by Dutch banks run for the last three years, but it is still too soon to assess their impact on small farmers.

Seeing the two cases from a comparative perspective, the faster adoption of the EU acquis by Croatia and the better organisation of the Croatian administration than the Turkish one had a positive impact on the implementation of the programmes. Yet, the diffusion of the EU principles and acquis are not sufficient factors to determine the success of the programmes. The different historical background of the countries, the configuration of power between the state and the civil society and the distribution of power between the different agricultural producers are crucial factors that explain the implementation of the reformed rural development policies and why particular groups have benefited so far from the EU funds.

A common characteristic of the two countries is the efforts that they did to deregulate their agri-food sectors for the last two decades (more than three decades in Turkey). Through privatisations of state companies (such as Kutjevo d.d, Orahovica and IPK Croatia in Croatia and TURKSEKER and TEKEL in Turkey) and the gradual elimination of subsidies, both countries wanted to show their commitment to a more liberal Europeanism. Yet, in the Croatian case, the new administrations of the 2000s wanted to leave behind the Tudjmanist centralised form of governance. Another objective of the government was to make the Croatian policies more transparent, an aim that in the agricultural sector was materialized through the participation of NGOs and civil society networks in the development of the national rural strategy. The participation of CSOs and pressures from below benefited small producers, despite the existence of several problems during the implementation of the programmes.

The pro-EU rhetoric of AKP (at least until the Eurozone crisis) highlighted in a similar manner with the Croatian government the commitment of Turkey to the EU project. Yet, the 
domestic politics in Turkey are different. The fragile Turkish coalition government of the 1990s favored the Turkish smallholders through generous prices and credit subsidies, as its leaders thought in old school populist terms to attract rural votes. ${ }^{44}$ However, the attrition of the agricultural sector during the 2000s, the consolidation of a strong government and the proliberal policies during the last decade (supported by projects from the World Bank) have favored primarily large farmers. The authoritative manner of the Turkish administration has further established the position of large producers, as the Ministry of Agriculture and Rural Affairs is unable to involve the majority of smallholders in the decision-making process. ${ }^{45}$ Rural CSOs, which could support smaller farmers, are weak and find it difficult to facilitate integrated rural development projects. The implementation of national plans, with the support of EU funds, continues this pattern and asymmetrically benefits the richer regions of the country and reproduces the power of wealthier farmers.

\section{The implementation of ENPARD in Egypt and Tunisia: Continuing the work of the ENP Action Plans}

Until 2014 and only for the preparation of the start-up phase of ENPARD in Egypt, Tunisia, Morocco and Jordan the EU has committed $€ 2,8 \mathrm{~m} .{ }^{46}$ The total budget for the implementation of the programme in the next four years in Tunisia is $€ 25 \mathrm{~m}$ and for Egypt is $€ 36 \mathrm{~m}$.

The commitment of the EU to inclusive growth and to the creation of more jobs is mentioned in statements of policymakers and in EC's strategy papers after the Arab Spring. ${ }^{47}$ But besides the change in the rhetoric of the new ENP initiative, the objectives of the pilot programmes in Egypt and Tunisia do not deviate far from the aims of the ENP Action Plans (APs) that were signed before the Arab revolts. ENPARD pilot projects in the two countries support the sustainable development of rural areas, various income-generating activities and help producers to meet the requirements of the national and international markets. ${ }^{48}$ The Egyptian Action Fiche for the implementation of ENPARD sets the objectives of the initiative more clearly. These include

the sustainable use of natural agricultural resources, increasing the productivity of land and water units, raising the degree of food security, increasing the competitiveness of agricultural products, improving the living standards of the rural inhabitants and reducing poverty rates in rural areas. ${ }^{49}$

In a similar vein the APs suggested reforms that would improve the Sanitary and Phyto-Sanitary (SPS) controls of the North African products and would encourage private investment in agriculture. According to the APs, the aims of these interventions are to improve the health safety of food for consumers and facilitate trade in agricultural products with the EU'. ${ }^{50}$ The 
ENP partners' export potential to the EU market would alleviate poverty and support rural development. 51

Besides the similarities between the ENP APs and ENPARD, what must be underlined is the fact that the promise of the EU to support inclusive growth in the ENP countries relies on the national strategies of the partners. ENPARD assists national schemes in order to offer to the partner countries 'an opportunity for enhanced cooperation in the fields of agriculture and rural development supporting them to build and implement their policy framework' [Emphasis added]. ${ }^{52}$

The rhetoric of the programme emphasises the open and collaborative character of the process with the aim to demonstrate that it is jointly owned by both sides. This is underlined in the flyer of the initiative, which highlights the ownership of ENPARD by the partner countries, which have the responsibility of all the elements of ENPARD (such as the selection of the pilot areas and the implementation of the programme). ${ }^{53}$ The objective of the EU is to show that it does not dictate its views to its neighbours. As part of an equal partnership, the EU supports Arab plans for the development of the North African agricultural sector. Through workshops the EU member states transfer their experiences to the ENP partners and assist them for making reforms that will 'make agriculture a focal sector in their cooperation with the EU'.54

Given that the national authorities of the ENP countries are responsible for ENPARD and that the new initiative has the same objectives with the existing APs, research needs to make a step back (as in the cases of Croatia and Turkey) and investigate what exactly the EU has supported so far. Starting the analysis from the application of high standards for food products, someone can see that the introduction of best practices for food hygiene has benefited until today the wealthier North African farmers, who export their crops to the EU.

The application of SPS controls has increased the costs of production to unbearable levels for the small North African farmers. There is a wide bibliography about the barriers that SPS controls raise to small producers of developing countries and how they contribute to their exclusion from international markets. ${ }^{55}$ In the North African case, the EUREPGAP certificate costs about $€ 1000$ per farm, but the infrastructure to get it costs to a North African farmer about $€ 60000$ only for the first year of production. ${ }^{56}$ The EU expects from North African producers to build expensive infrastructure, such as water management facilities, which can be undertaken only by large farmers. For example, for the implementation of EUREPGAP and for exporting citrus to the EU, a North African farmer needs four hundred hectares of land and for the production of tomatoes a farm must be larger than ten hectares. ${ }^{57}$

The fact that SPS measures require large-scale investments over extended periods of time has contributed to the creation of a bimodal agricultural market that distinguishes farmers into exporters that prefer to sell their products to the EU market for higher returns and into substitute farmers that receive limited assistance and refuse to switch to market-driven crops 
in order to survive. ENPARD continues to support such dichotomies by offering technical assistance only for the production of export-oriented crops. The Tunisian programme aims to improve the connection of the domestic production to markets, ${ }^{58}$ while in the Action Fiche for the implementation of the programme in Egypt it is clearly stated that the expected main activities include support to 'main commercial crops (olives, figs) processed locally'. ${ }^{59}$ Such approaches indicate that subsistence farmers, who do not cultivate these crops will remain excluded from the programme.

Another important element of ENPARD is the emphasis of the programme in the poor managerial skills of small farmers. The EU and the partner countries acknowledge the limited access of small farmers to finance and their 'lack of technical/managerial skills' ${ }^{60}$ This situation suffocates small landholders, whose 'income from agricultural activities is not sufficient to meet their needs' ${ }^{61}$

This is not the first time that policymakers mention the problems that derive from the poor managerial skills of small farmers. In the past such arguments were used by the Egyptian and the Tunisian authorities as an organising framework for policies that deregulated the land market; ${ }^{62}$ and led to a rapid increase of land prices. ${ }^{63}$ After the Arab revolts the EU's Twinning programmes continue to support a discourse that assist the reproduction of such neoliberal practices. $^{64}$

ENPARD enriches this narrative by highlighting the poor entrepreneurial skills of small farmers as one of the main reasons for increasing environmental degradation in the region. ${ }^{65}$ The programme claims that it will promote eco-responsible practices and procedures; ${ }^{66}$ and will 'focus on 'sustainable management of territorial resources' ${ }^{67}$ The need for irrigation projects is stressed and the EC highlights the efforts of the Egyptian government to improve farm irrigation techniques. ${ }^{68}$

However, what should be noted here is that schemes which were meant to solve the problem of water supply for the Egyptian economy led to asymmetrical gains and distribution of water. Many researches have shown so far that Egypt's irrigation projects have promoted environmental crises and have offered opportunities for asset stripping. ${ }^{69}$ Previous schemes decreased the water supplies for the farmers of the Delta and irrigation disputes and rural violence have increased during the last decade. ${ }^{70}$ The danger of offering help to such projects is very high, as the EU keeps perceiving agricultural growth as a matter of management skills, water and land supply. This situation allowed the creation of strategies that have neglected small farmers; ${ }^{71}$ and reproduced the power of the central authorities of the two countries in rural areas (as the sole organiser of irrigation schemes).

ENPARD attempts to mitigate the effects of this last issue, by following the decentralised approach of IPARD. In the Tunisian version of the programme it is clearly stated that its specific objective is to promote processes of consultation and co-management at 
different levels, between government, business and local stakeholders [...] for the economic and social integration of all agricultural and rural groups, with a particular focus on the most vulnerable'.$^{72}$

In a similar vein, the Egyptian plan is to strengthen the capacity of rural associations and community-based organisations. ${ }^{73}$ As in the case of IPARD, the creation of LAGs is a precondition for the successful implementation of ENPARD. The inclusion of local CSOs is perceived as a tool that will balance the power of the North African central administrations by giving more ownership to local stakeholders (especially to women and youth). Yet, two issues should be highlighted regarding the participation of North African CSOs in ENPARD. First, the two ENP countries do not allow the same space for the participation of CSOs in development projects. Before the Arab Spring, Mubarak's regime was criticised by NGOs and the EU institutions for the barriers it put to the operation of CSOs. ${ }^{74}$ Before its fall more than 150 NGOs complained against the interventions of the government, which tried to restrict the work of CSOs through stricter rules of registration and foreign funding. ${ }^{75}$ Due to his religious conservatism, Morsi has maintained the limited space for the work of secular NGOs. Baroness Ashton has expressed the worries of the EU for the new hegemony of Islamist parties in Egypt; ${ }^{76}$ and the ENP progress report of 2012 highlighted the EU concerns for the suffocation of women rights and the status of NGOs. ${ }^{77}$ After the ousting of Morsi, Sisi has appeared as the savior of Egypt and many CSOs, especially women's rights activists, mention his military background and blame him for pursuing a political context similar to this of the Mubarak's era. ${ }^{78}$

This context promotes subtle forms of containment; ${ }^{79}$ and permits the work of CSOs that have close ties with the government and are elitist in nature, without reflecting the majority of the Egyptian society. ${ }^{80}$ In rural Egypt, the very few organisations that represent small farmers do not have the capacity to influence the design of development projects; ${ }^{81}$ and NGOs with Islamic affiliation are the most active actors in many rural governorates. ${ }^{82}$ These NGOs are excluded from EU funding and keeping in mind the fact that the existing agricultural policies support primarily export-oriented farmers, there is a threat of turning LAGs into an instrument that will promote big landowners' preferences at the local level. Such developments could undermine the objective of ENPARD for inclusive growth. In Tunisia CSOs play a more important role in public affairs and women's associations are more meaningful actors in rural areas than in Egypt. Their role can counterbalance the liberal restructuring of agriculture, but the risk of using LAGs for the benefit of wealthier farmers still exists. Without careful management ENPARD can repeat the mistake of other rural programmes in the country, which aimed to benefit marginalised groups of rural communities, but at the end they did not help the poorest. Projects funded by the UN with similar goals to ENPARD (such as the Oued Sbaihya project) generated processes of both inclusion and exclusion. Women that lived in households 
with small land and low income were found in worse position and with greater debts after the application of the programmes. ${ }^{83}$

The last issue that deserves attention is the aim of ENPARD to offer training to women and young people of the two countries. In both countries the related documents mention the 'particular attention that is paid to the inclusion of young people [...] and women [...]. These groups are explicitly targeted in several programme activities such as professional training ${ }^{\prime}{ }^{84}$ Further details about the organisation of these training workshops are not available yet, but again previous experience shows that in many cases women are underrepresented and their non-involvement is a result of low levels of schooling or persisting illiteracy. ${ }^{85}$ According to UNICEF, the literacy level of Egyptian women (86,1 per cent) is lower than this of the Tunisians $(96,1$ per cent $) ; 6$ and based on these facts, the Tunisian training programme has more chances for success. Yet again the design of the training sessions and access to credit are matters of paramount importance for these groups. Women that have participated in similar workshops in the past did not qualify for loans to pursue their own initiatives and their income remained low. ${ }^{87}$ Often the skills that rural youth and women acquire from such technical workshops prepare them for off-farm working and lead to urbanisation rather than to rural development.

\section{Conclusion}

The analysis of the four case studies highlights the need to differentiate policy diffusion from convergence and to assess the role that domestic policies play in policy success. Domestic policies respond to political, economic and social contestations and they benefit specific subgroups of the farming communities. Despite several problems that emerged during the implementation of the EU programmes, pressures from small producers, the role of rural associations and the need to decentralise the governance system led the Croatian administration to plans that offer significant support to small and medium farmers. On the other hand, the Tunisian and Egyptian cases share more similarities with the Turkish experience. In these three countries the liberalisation of the agricultural market has further marginalised small producers. Their administrations offer marginal help to small farmers and the ENP APs support North African policies that increase the gap between large and small framers.

According to the findings of this research, ENPARD diffuses the new EU principles of rural development, but at the same time it continues the work of the APs with very few changes. The new initiative attempts to offer support to marginalised groups of rural communities, but the introduction of NGOs and vocational training to women and youth is offset by the limited role that CSOs play in North Africa (especially in Egypt) and the problematic access of small farmers to credit. In addition, the new programme continues to offer funds for the production of commercial crops and to reinforce national strategies, which 
so far benefit primarily export-oriented producers. By having ENPARD as the basis for the conclusion of the agricultural component of the Deep and Comprehensive Free Trade Agreements that the EU wants to sign with the partners, the EU continues to perpetuate economic models that have failed in the past and which have concentrated the wealth of these societies to the hands of very few people. ${ }^{88}$ Under these conditions, it is very unlikely to see ENPARD becoming a successful tool for the rural development of the two North African countries.

\section{Author's details}

Author: Dr. Christos Kourtelis

Assistant Professor of International Relations

Department of Political Science and International Relations

Antalya International University

Çıplaklı Mah. Farabi Cad.

No:23 Döşemealtı/Antalya, Turkey

christos.kourtelis@antalya.edu.tr

\section{Notes}

${ }^{1}$ Gstöhl, S. (2008). A Neighbourhood Economic Community -finalité économique for the ENP? (EU Diplomacy Papers No. 3). Bruges: College of Europe.; Gänzle, S. (2009). EU Governance and the European Neighbourhood Policy: A Framework for Analysis. Europe-Asia Studies, 61(10), 1715-1734.; Börzel, T. A. (2010). The Transformative Power of Europe Reloaded The Limits of External Europeanization (Working Paper No. 11). Berlin; Börzel, T., \& Risse, T. (2012). From Europeanisation to Diffusion: Introduction. West European Politics, 35(1), 1-19.

2 Hunt, D. (2005). Implications of the free trade agreements between the EU and the Maghrib economies for employment in the latter, given current trends in North African exports: Cline's fallacy of composition revisited. The Journal of North African Studies, 10(2), 201-221.; Emlinger, C., Jacquet, F., \& Lozza, E. C. (2008). Tariffs and other trade costs: assessing obstacles to Mediterranean countries' access to EU-15 fruit and vegetable markets. European Review of Agricultural Economics, 35(4), 409-438.

3 European Commission. (2011). A New Response to a Changing Neighbourhood A review of European Neighbourhood Policy (No. COM (2011) 303). Brussels: European Commission; European Commission. (2012). Delivering on a new European Neighbourhood Policy (No. JOIN (2012) 14 final). Brussels: European Commission; European Commission. (2012, May 31). New Commission approach on agriculture in Neighbourhood launched. http://ec.europa.eu/europeaid/news/31-05-2012 enpard en.htm (03/03/2013) 
${ }^{4}$ Ibid.

5 Ibid.

${ }^{6}$ Bengtsson, R. (2008). Constructing Interfaces: the Neighbourhood Discourse in EU External Policy. Journal of European Integration, 30(5), 597-616; Börzel, \& Risse, op.cit; Lavenex, S., \& Schimmelfennig, F. (2009). EU rules beyond EU borders: theorizing external governance in European politics. Journal of European Public Policy, 16(6), 791-812; Schimmelfennig, F. (2009). Europeanization beyond Europe. Living Reviews in European Governance, 4(3), 1-24

7 Knill, C. (2005). Introduction: Cross-national policy convergence: concepts, approaches and explanatory factors. Journal of European Public Policy, 12(5), 764-774.

${ }^{8}$ Holden, P. (2009). In Search of Structural Power: EU Aid Policy as a Global Political Instrument. Ashgate Publishing, Ltd.

${ }^{9}$ Börzel, \& Risse, op.cit

10 Börzel, \& Risse, op.cit

11 Radaelli, C. M. (2005). Diffusion without convergence: how political context shapes the adoption of regulatory impact assessment. Journal of European Public Policy, 12(5), 924-943.

12 Ibid.

${ }^{13}$ Ward, N. (2002). Integrated rural development - a review of the literature. Trondheim: Centre for Rural Research, University of Trondheim.

14 The Cork Declaration. (1997). LEADER Magazine, (13).

${ }^{15}$ European Commission. (2012). ENPARD Conference on Strategic Modernisation of Agriculture in EU Neighbourhood countries (31/05-01/06/2012, Brussels).

http://ec.europa.eu/agriculture/events/enpard-workshop-2012 en.htm (03/03/2013) 16 Ibid.

17 Republic of Croatia Ministry of Agriculture, Fisheries and Rural Development. (2009). IPARD Programme 2007-2013. Zagreb.; World Bank. (2016). The World Bank Agriculture and Rural Development. http://data.worldbank.org/indicator (16/01/2016)

18 The Republic of Turkey Prime Ministry Investment Support and Promotion Agency. (n.d.). Invest in Turkey., http://www.invest.gov.tr/en-US/sectors/Pages/Agriculture.aspx (03/03/2014);

19 SAPARD was a Community framework for supporting sustainable agricultural and rural development in the Central and Eastern European applicant countries.

${ }^{20}$ Delegation of the European Union to the Republic of Croatia. (n.d.). SAPARD - Programme for Agriculture \& Rural Development. http://www.delhrv.ec.europa.eu/?lang=en\&content=1286 $(16 / 01 / 2016)$ 
${ }^{21}$ Mikuš, O., Mesić, Ž., \& Cerjak, M. (2010). Review of agriculture and agricultural policy in Croatia. In T. Volk (Ed.), Agriculture in the Western Balkan countries (Vol. 57). Halle: Leibniz Institute of Agricultural Development in Central and Eastern Europe.

${ }^{22}$ Republic of Croatia Ministry of Agriculture, Fisheries and Rural Development, op.cit.

23 Petak, Z. (2011). Politics of Decentralization Policy: Explaining the Limited Success of the Croatian Case after 2001. Politička Misao, 48(5), 72-84.

${ }^{24}$ Petak op.cit; Šeparović, P. (2001) The Reform of Local Self-Government in Croatia. in Local Self Government and Decentralization in South-East Europe (Friedrich Ebert Stiftung).; Petak, Z. (2006). Policy in a Transitional context: Performing Decentralization in Croatia. In Colebatch. $\mathrm{H}$ (Ed.), The Work of Policy. Lanham: Lexington.; Petak 'Politics of Decentralization Policy: Explaining the Limited Success of the Croatian Case after 2001' op.cit.

25 Tusek, Z. (2014). Accreditation of the Paying Agency: The Croatian Experience. Presented at the 35th Conference of the Directors of EU Paying Agencies, Komotini.

${ }^{26}$ Bezovan, G. (2001). Croatian Civil Society: On the path of becoming a legitimate public actor (CIVICUS Index on Civil Society Occasional Paper Series). Zagreb: Centre for Development of Non-Profit Organizations.

${ }^{27}$ Republic of Croatia Ministry of Agriculture, Fisheries and Rural Development, op.cit.,p.200

28 Möllers, J., Zier, P., Frohberg, K., Buchenrieder, G., \& Bojnec, S. (2009). Croatia's EU Accession: Socio-economic Assessment of Farm Households and Policy Recommendations (Vol. 48). Halle: Leibniz Institute of Agricultural Development in Central and Eastern Europe.

${ }^{29}$ Republic of Croatia Ministry of Agriculture, Fisheries and Rural Development, op.cit.,p.43

30 Andrlic, B., Devcic, A., \& Hak, M. (2013). Development of Rural Tourism in Eastern (Pannonian) Croatia: The Implementation of IPARD Fund. Journal of International Scientific Publications: Agriculture \& Food, 1(1).

${ }^{31}$ Croatian Rural Development Network. (n.d.). Shadow report on implementation of the IPARD programme in Croatia 2010 - 2012. http://www.hmrr.hr/en/rural-development/ipard/ (03/03/2014)

32 Konya, E. (2012). Impact of the SAPARD Programme on the Rural Development System in Eastern-Central European Countries. Szent Istvan University Godollo, Godollo.

33 Open Society Fund BH. (n.d.). How Politics Goes About Destroying Agriculture. http://www.vpi.ba/upload/documents/Engl manipulacijama protiv agrarne reforme.pdf (05/07/2015)

${ }^{34}$ Petak 'Politics of Decentralization Policy: Explaining the Limited Success of the Croatian Case after 2001; op.cit. p.79 
${ }^{35}$ Host, A., \& llibašić, J. (2011). Pre Accession Negotiations of Croatia and Adjustment to the EU Agricultural Policy. In Case studies on specifics of national economic policies related to economic integration II. Opatija. http://oliver.efri.hr/ euconf/2011/session8.html (07/07/2015) ${ }^{36}$ Croatian Rural Development Network,op.cit.

37 Oxford Business Group. (2008). Turkey 2008. Oxford: Oxford Business Group.

${ }^{38}$ Serefoglu, C., \& Atsan, T. (2012). The impact of the EU instrument for pre-accession for rural development (IPARD) to Turkey, Management, Economic Engineering and Rural Development 12(4).

${ }^{39}$ Cakmak, E. (2004). Structural Change and Market Opening in Agriculture: Turkey towards EU Accession (Working Paper No. 04/10). Ankara: Economic Research Center.

${ }^{40}$ Kasnakoglu, H., \& Cakmak, E. (2000). Country Agricultural Policy Notes: Turkey. In A. Valdés (Ed.), Agricultural Support Policies in Transition Economies. Washington, DC: World Bank Publications.; Kose, M. (2012). Agricultural policy reforms and their implications on rural development: Turkey and the EU. Ankara Avrupa Çalışmaları Dergisi, 11(2), 75-98.

${ }^{41}$ Serefoglu \& Atsan, op.cit.

${ }^{42}$ Allen, F., \& Ozcan, N. (2006). Rural Development in EU - Turkey (No. REX/219). Kayseri: EUTurkey Joint Consultative Committee.; OECD. (2011). Evaluation of Agricultural Policy Reforms in Turkey. OECD Publishing.

${ }^{43}$ Allen \& Ozcan, op.cit; Ozdemir, G. (2013). Women's Cooperatives in Turkey. Procedia - Social and Behavioral Sciences, 81, 300-305.

${ }^{44}$ Geyder, C., \& Yenal, Z. (2011). Agrarian Change under Globalization: Markets and Insecurity in Turkish Agriculture. Journal of Agrarian Change, 11(1), 60-86.

${ }^{45}$ Agunga, R., Gul, A., \& Budak, D. B. (2013). Communication for Development as a Strategy to Enhance Agricultural Extension Performance In Turkey. Journal of Agricultural Extension, 17(2), 190-199.

${ }^{46}$ EU Neighbourhood Info Centre. (n.d.). Support to the European Neighbourhood Programme for Agriculture and Rural Development (ENPARD) http://www.enpiinfo.eu/mainmed.php?id=582\&id type=10 (21/07/2014)

${ }^{47}$ European Commission. (2011). A New Response to a Changing Neighbourhood A review of European Neighbourhood Policy (No. COM (2011) 303). Brussels: European Commission.; European Commission. (2012). Delivering on a new European Neighbourhood Policy, op.cit.

48 The European Neighbourhood Programme for Agriculture and Rural Development. (n.d.). http://www.enpard.iamm.fr/en/presentation/partnership-offer (06/06/2014)

${ }^{49}$ European Commission. (2013). Action Fiche for the Joint EU Rural Development Programme under the ENPARD initiative. European Commission., p.3.

${ }^{50}$ European Commission. (2004). EU/Tunisia Action Plan. Brussels., p.12. 
http://ec.europa.eu/world/enp/pdf/action plans/tunisia enp ap final en.pdf (03/03/2014); European Commission. (2006). EU/Egypt Action Plan. Brussels., p.13.

http://ec.europa.eu/world/enp/pdf/action plans/egypt enp ap final en.pdf (03/03/2014) 51 Ibid., p.9.

52 The European Neighbourhood Programme for Agriculture and Rural Development. (n.d.), op.cit.

$53 \mathrm{lbid}$.

54 European Commission. (2012). 'ENPARD Conference on Strategic Modernisation of Agriculture in EU Neighbourhood countries' op.cit.

55 Petrey, L. A., \& Johnson, R. W. M. (1993). Agriculture in the Uruguay Round: Sanitary and Phytosanitary Measures. Review of Marketing and Agricultural Economics, 61(3).; Sykes, A. O. (1995). Product Standards for Internationally Integrated Goods Markets. Brookings Institution Press.' Jaffee, S. (1999). Southern African Agribusiness: Gaining Through Regional Collaboration. Washington, DC: World Bank Publications.; Henson, S., \& Loader, R. (2001). Barriers to Agricultural Exports from Developing Countries: The Role of Sanitary and Phytosanitary Requirements. World Development, 29(1), 85-102.; Otsuki, T., Wilson, J., \& Sewadeh, M. (2012). Measuring the effect of food safety standards on African exports to Europe. In K. Anderson, C. F. McRae, \& D. W. Wilson (Eds.), The Economics of Quarantine and the SPS Agreement. Canberra: University of Adelaide Press.

${ }^{56}$ Aloui, O., \& Lahcen, K. (2004). The Cost of Compliance with SPS Standards for Moroccan Exports: A Case Study (Discussion Paper). Washington, DC: The World Bank. p.20

57 Ibid., p.20.; Cadot, O., Augier, P., Gourdon, J., \& Malouche, M. (2012). Non-tariff measures in the MNA region: Improving governance for competitiveness (Working Paper No. 56). IBRD/World Bank., p. 16.

${ }^{58} \mathrm{CIHEAM}$-IAMM. (n.d.). ENPARD Tunisia: The pilot Action Programme under ENPARD. CIHEAMIAMM.

${ }^{59}$ European Commission. (2013). Action Fiche for the Joint EU Rural Development Programme under the ENPARD initiative. op.cit., p.7.

60 Ibid., p.4.

61 Ibid., p.6.

62 Cheterian, V. (2010). Environmental pressure, neoliberal reforms, and geopolitical competition in the Maghreb. The Journal of North African Studies, 15(2), 255-264.

63 Jouili, M. (2009). Tunisian agriculture: Are small farms doomed to disappear? (No. 52816). 111th Seminar, June 26-27, 2009, Canterbury, UK: European Association of Agricultural Economists. http://econpapers.repec.org/paper/agseaa111/52816.htm (03/03/2016) 
${ }^{64}$ işleyen, B. (2015). The European Union and neoliberal governmentality: Twinning in Tunisia and Egypt. European Journal of International Relations, 21(3), 672-690.

${ }^{65}$ European Commission. (2013). Action Fiche for the Joint EU Rural Development Programme under the ENPARD initiative. op.cit., p.4.

${ }^{66}$ CIHEAM-IAMM. (n.d.).op.cit.

${ }^{67}$ European Commission. (2013). Action Fiche for the Joint EU Rural Development Programme under the ENPARD initiative. op.cit., p.6.

${ }^{68}$ European Commission. (2013). Action Fiche for the Joint EU Rural Development Programme under the ENPARD initiative. op.cit., p.3.

${ }^{69}$ El-Agha, D. E., Molden, D. J., \& Ghanem, A. M. (2011). Performance assessment of irrigation water management in old lands of the Nile delta of Egypt. Irrigation and Drainage Systems, 25(4), 215-236.; Clausen, S. T., Clausen, T. W., Simonsen, L. W., Back, Y., \& Hornung, L. (2014). Irrigation technologies and agricultural expansion into the New Valley, Egypt (Thesis). http://rudar.ruc.dk/handle/1800/13136 (04/06/2015)

${ }^{70}$ Bush, R. (2007). Politics, power and poverty: twenty years of agricultural reform and market liberalisation in Egypt. Third World Quarterly, 28(8), 1599-1615. p.1607; Bush, R. (2011). Coalitions for Dispossession and Networks of Resistance? Land, Politics and Agrarian Reform in Egypt. British Journal of Middle Eastern Studies, 38(3), 391-405., p. 398.

${ }^{71}$ Bush, R. (2007). op.cit., p.1600.

${ }^{72}$ CIHEAM-IAMM. (n.d.).op.cit.

${ }^{73}$ European Commission. (2013). Action Fiche for the Joint EU Rural Development Programme under the ENPARD initiative. op.cit., p.8.

${ }^{74}$ European Commission. (2010). Implementation of the European Neighbourhood Policy in 2009 Progress Report Egypt (No. SEC(2010) 517). Brussels: European Commission.

75 Guirguis, D. (2009). Egypt's NGO Bill Imperils Civil Society Funding. http://carnegieendowment.org/2009/02/03/egypt-s-ngo-bill-imperils-civil-societyfunding/few4 (27/08/2014)

${ }^{76}$ Pinfari, M. (2013). The EU, Egypt and Morsi's Rise and Fall: "Strategic Patience" and Its Discontents. Mediterranean Politics, 18(3), 460-466.

77 European Commission. (2013). Implementation of the European Neighbourhood Policy in Egypt Progress Report in 2012 and recommendations for actions (No. SWD(2013) 89 final). Brussels: European Commission., pp.2,5.

78 Rabie, D. (2014). Sisi and his women. http://www.madamasr.com/content/sisi-and-hiswomen $(27 / 08 / 2014)$

${ }^{79}$ Kausch, K. (2009). Defenders in Retreat Freedom of Association and Civil Society in Egypt (Working Paper No. 82). Madrid: FRIDE., p.3. 
${ }^{80}$ Hamdy, H. (2011). Civil Society in Egypt under the Mubarak Regime. Afro Asian Journal of Social Sciences, 2(2).

${ }^{81}$ Ghanem, H. (2014). Improving Regional and Rural Development for Inclusive Growth in Egypt (Working Paper 67). Washington, DC: Brookings Institution.

82 Allam, R. (2012). Engaging with traditional and modern Islamic NGOs in Egypt (Policy Brief 3). Cairo: Flemish Institute.

${ }^{83}$ Gana, A. (2012). Poverty Alleviation Through Microcredit: The Impact of the Oued Sbaihya Project on the Sustainable Management of Natural Resources and Rural Women's Empowerment in Tunisia. Cornell Journal of Law and Public Policy, 22(685).

${ }^{84}$ CIHEAM-IAMM. (n.d.).op.cit., p.2; European Commission. (2013). Action Fiche for the Joint EU Rural Development Programme under the ENPARD initiative. op.cit., p.13

$85 \mathrm{Hartl}, \mathrm{M}$. (2009). Technical and vocational education and training and skills development for poverty reduction - do rural women benefit? Presented at the FAO-IFAD-ILO Workshop on gaps, trends and current research in gender dimensions of agricultural and rural employment, Rome., p.2

${ }^{86}$ UNICEF. (2013). Statistics Egypt. http://www.unicef.org/infobycountry/egypt_statistics.html (27/08/2014); UNICEF. (2013); Statistics Tunisia. http://www.unicef.org/infobycountry/Tunisia statistics.html (27/08/2014)

${ }^{87}$ Hartl, op.cit., p.9; Khafagy, F. (2009). Shadow NGO Report on Egypt's fourth and fifth Combined Periodic Report to the Committee on the Elimination of Discrimination against women. Cairo: Alliance for Arab Women.

${ }^{88}$ Dennison, $S$ (2013). The EU and North Africa after the Revolutions: A new start or 'plus ca change'?. Mediterranean Politics, 18:1, 123-128., p.3. 